\title{
Study on the Behaviour of the Luting Cement for Aesthetic Inlays
}

\author{
ANCA VITALARIU, MONICA TATARCIUC, ODETTE LUCA*, CATALINA HOLBAN- CIOLOCA, OVIDIU NICOLAICIUC, \\ DIANA DIACONU-POPA \\ Grigore T. Popa University of Medicine and Pharmacy Iasi, Department of Removable Prosthesis, Oral Implantology and Dental Technology, \\ 16 Universitatii Str., 700115 Iasi, Romania
}

The clinical success of any indirect prosthodontic restoration is strongly related, among other numerous factors, to the fixing procedure. The technological deficiencies into the inlay cementation lead to defects, either in depth or on surface, which often cause failures. The longevity of inlays depends, to a large extent, on the quality of the dental-prosthetic joint. This marginal adaptation is influenced by the thickness and the type of the luting cement. The aim of this study is a comparative analysis on the behavior of the luting cement for composite resin and ceramic inlays in two different solutions: ANFOR-type artificial saliva and a $20 \%$ citric acid solution. Fixing composites are the material of choice for works with high aesthetic potential, our study revealing that their depreciation and alteration is reduced, even in aggressive environments. Cementation seems to be the most critical step, and its long-term success relies on adherence to the clinical protocols

Keywords: inlay, dental-prosthetic joint, marginal fitting, luting cement

Inlays are used today on a larger scale, tending to replace direct fillings. This restorations, realized by indirect methods (made by dental technician in the laboratory), have optimized mechanical and biological parameters and, implicitly, superior clinical properties. Also, these indirect reconstruction methods allow a very accurate restoration of the teeth morphology - both occlusal and proximal details - especially of the contact area $[1,2]$.

The aesthetic requirements are extremely high nowadays, and the modern materials - composite resins and ceramic systems - have to respond to both physiognomic and mechanical demands, in order to be successfully used for inlay-type coronary reconstructions.

The longevity of these high precision restorations depends also, to a large extent, on the quality of the dental-prosthetic joint, the depreciation of the fixing material leading to deficiencies at the level of the tooth-restoration interface [3,4]. The smaller the space at the tooth-restoration interface, the thinner the resin film, the lower the polymerization contraction and the more resistant the material, the better the marginal adaptation on the long term.

In the literature there is a controversy about the material of choice for aesthetic inlays, each of the two materials composite resins and ceramic - having advantages and disadvantages as well.

As for the marginal adaptation, this is influenced, on the one hand, by the space existing at the tooth-restoration interface, and on the other hand by the nature of the fixing material [5-10].

In this study we aimed a comparative analysis of the behavior of the different luting materials in different conditions. As the composite fixing resins suffer most changes in the grip reaction, we focused our research on analyzing the stress generated by the polymerization contraction of these materials at the level.

\section{Experimental part}

The study was performed on 60 premolars, extracted from periodontal or orthodontic reasons. The teeth were cleaned of any traces of periodontal tissue or tartar deposits, using a Gracey curette, washed with a $2 \%$ sodium hypochlorite solution, and then kept in distilled water for one week; at the coronary level, mesio-occlusal-distal cavities were performed, using diamond burs, under continuous cooling. The occlusal cavity was $3 \mathrm{~mm}$ depth at the isthmus level between the horizontal and vertical cavities, the proximal cavities were prepared with a mesio-distal dimension of $4 \mathrm{~mm}$, and their cervical-occlusal diameter is also $3 \mathrm{~mm}$. The lateral walls of the occlusal and proximal cavities have a $6^{\circ}$ divergence towards the occlusal side, to allow the unforced insertion of the prosthetic piece; the cervical threshold was performed in a $90^{\circ}$ angle. All the angles were rounded to avoid the occurrence of internal tensions in the restoration and its fracture.

\footnotetext{
*email:lucaodette@yahoo.com
} 
The teeth were divided into two groups: a first one, consisting of 30 premolars, was restored with composite material, by indirect method, using SR Nexco resin (Ivoclar), a purely light-curing lab composite with micro-opal fillers, which allows achieving a lifelike shade, even if space is limited.

The other group was restored with ceramic inlays, made of IPS Empress system (Ivoclar), a leucite-based glassceramic extremely homogeneous, that scatters light naturally and provides a balanced chameleon effect.

The inlays were fixed using as material for 30 restorations (15 ceramic and 15 composite resin), Variolink N (Ivoclar) light curing composite resin, a double-cure and light-curing luting composite for glass-ceramic, lithium disilicate glassceramic and composite resin restorations.

Another 30 inlays (15 ceramic and 15 composite resin) were fixed with Meron Plus material (Voco), a glass ionomer cement, improved with resins.

To simulate the oral environment, two limit solutions were chosen: ANFOR-type artificial saliva and an acid solution, represented by citric acid. The artificial saliva only partially reproduces the inorganic component, excluding the organic and microbial component and has in composition $\mathrm{NaCl} 0,7 \mathrm{~g} / \mathrm{L}, \mathrm{KCl} 1,2 \mathrm{~g} / \mathrm{L}, \mathrm{Na}_{2} \mathrm{HPO}_{4} \mathrm{H}_{2} \mathrm{O} 0.26 \mathrm{~g} / \mathrm{L}, \mathrm{NaHCO} 31.5 \mathrm{~g} / \mathrm{L}$, KSCN $0.33 \mathrm{~g} / \mathrm{L}$, urea $1.35 \mathrm{~g} / \mathrm{L}$ and a pH of 6,78 . The citric acid, at $20 \%$ concentration, with a $\mathrm{pH}$ of 1.90 , is an aggressive environment, which can be accidentally encountered in the oral environment.

Ten samples were kept as control, and 25 samples were fixed with Variolink N resin (12 from composite resin and 13 from ceramic), were introduced into artificial saliva, which is a relatively mild corrosion agent, in which the samples were kept at $37^{\circ} \mathrm{C}$, for 70 hours.

The other 25 samples, fixed with Meron Plus material (12 from composite resin and 13 ceramic) were introduced into citric acid, where they were kept for 40 hours at $37^{\circ} \mathrm{C}$.

The teeth were sectioned in mesial-distal direction using diamond discs, at low speed, under cooling with water. The sections were examined using an optical microscope (Carl-Zeiss AxioImager. A2 with LED), coupled with a high resolution digital camera at 50x magnification.

\section{Results and discussions}

The initial microscopic aspect at the level of the tooth-restoration interface proves a very good marginal adaptation and the absence of defects or discontinuities of the Meron Plus fixing material in both type of inlays (composite and ceramic) (Figs. 1 and 2).

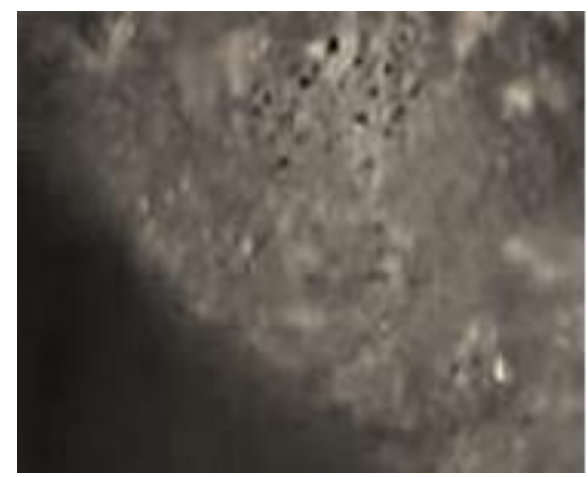

Fig.1. The composite inlays

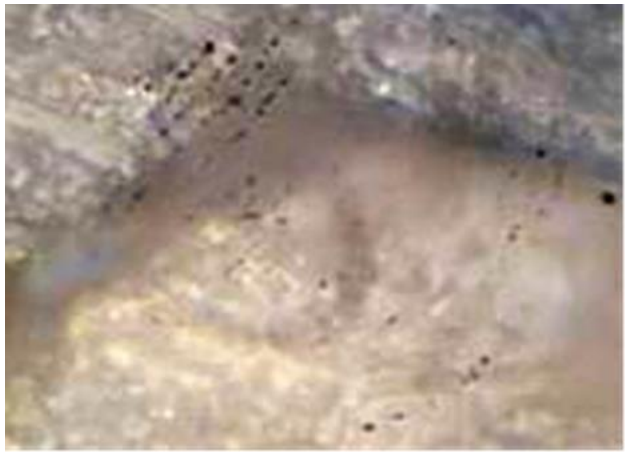

Fig. 2. The ceramic inlays

In case of inlays made of composite resin and ceramic fixed with Meron Plus, after 70 hours of immersion in AFNOR artificial saliva, a percolation space of approximately $0.005 \mathrm{~mm}$ appears at the level of the interface; in addition, there is a marked oscillation of level between the restoration surface and the cementing material. This fact indicates that after being maintained in the artificial saliva, the luting material will present irregularities and deep cracks. This may be due to the deterioration of the cement, the contraction of the grip or the absorption of water from the immersion environment.

There are no significant differences between the two types of restorations - composite and ceramic (Figs. 3 and 4). 


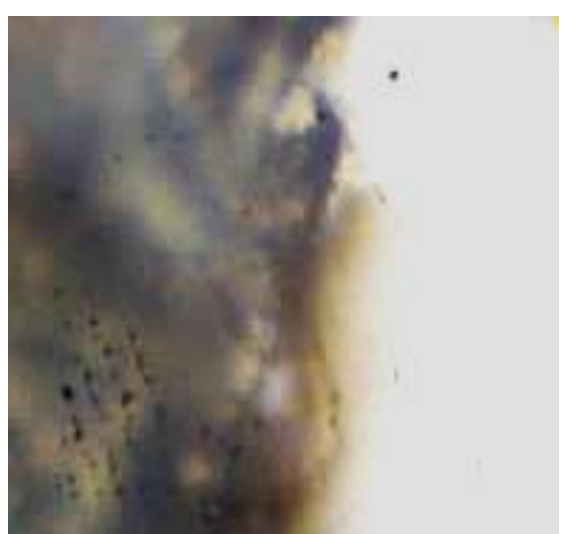

Fig. 3. The aspect of interface at the level of the composite restoration fixed with Meron Plus after the immersion in artificial saliva

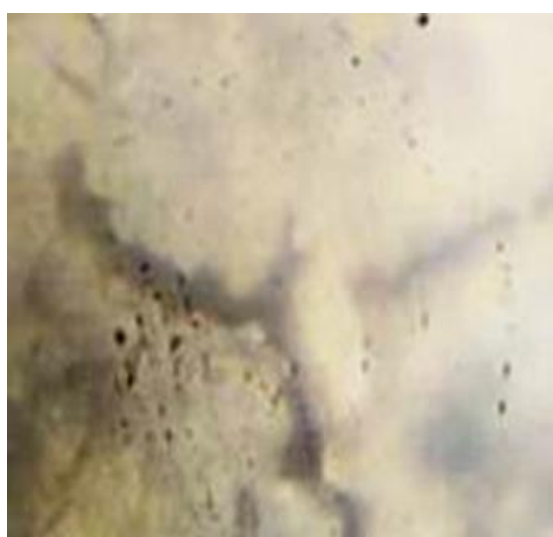

Fig. 3. The aspect of interface at the level of the ceramic restoration fixed with Meron Plus after the immersion in artificial saliva

After the immersion for 40 hours in citric acid, the fixing material, both in the case of composite and ceramic inlays, will be completely destroyed, observing the occurrence of an irregular space at the dental-prosthetic joint level (Figs. 4 and 5).

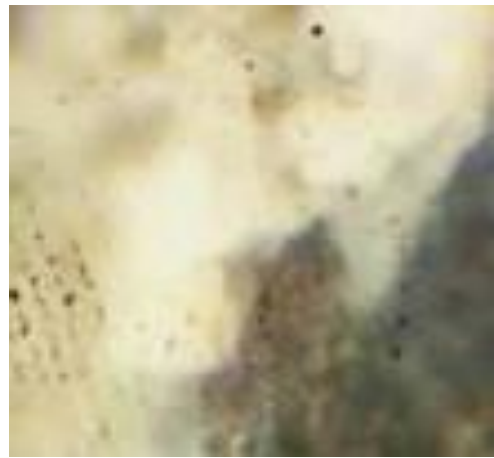

Fig. 4. The aspect of interface at the level of the composite restoration fixed with Meron Plus after immersion in $20 \%$ acid citric

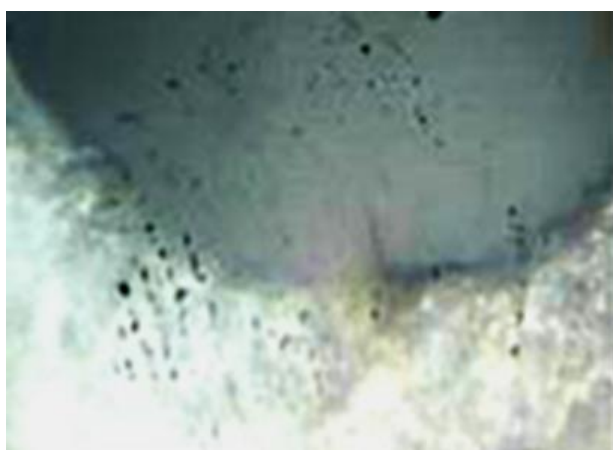

Fig. 5. The aspect of interface at the level of the ceramic restoration fixed with Meron Plus after immersion in $20 \%$ acid citric

The microscopic aspect of the interface in the case of inlays fixed with VariolinK $\mathrm{N}$ resin showed a very good marginal adaptation immediately after the fixing procedure, the connection surface having a continuous and homogeneous aspect, both in the case of composite and ceramics inlays

The absence of the percolation spaces proves a good adhesion between the luting material and inlay material, and no influence of the polymerization shrinkage on the dental-prosthetic joint.

There is a very good grip between the ceramic inlay and the Cavitan material; it is possible to notice the continuity of the outlet throughout the contour and the absence of the percolation spaces. (Figs. 6 and 7).

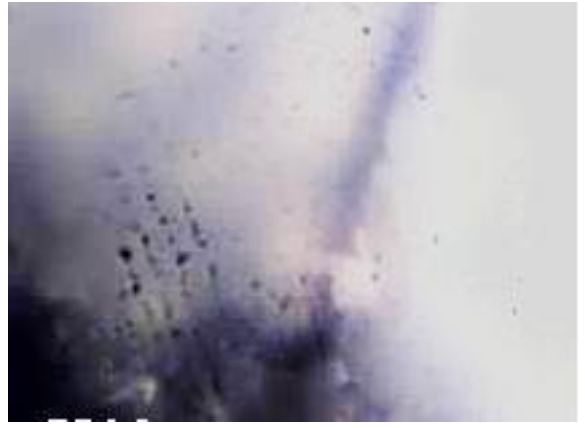

Fig.6 The initial aspect of interface at the level of composite restorations fixed with Variolink $\mathrm{N}$

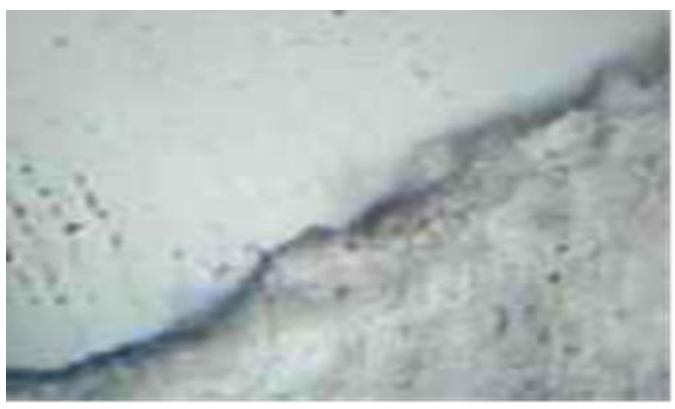

Fig.7. The initial aspect of interface at the level of ceramic restorations fixed with Variolink $\mathrm{N}$ 
After the immersion of the samples in the artificial saliva for 70 hours, at the level of the interface between the composite and the luting material, small cracks (of the order of $0.005 \ldots 0.01 \mathrm{~mm}$ ) are observed in the mass of the Variolink resin and loss of substance at the level of the restoration, which are, however, superficial and do not affect the quality of the dental-prosthetic joint (Fig. 8).

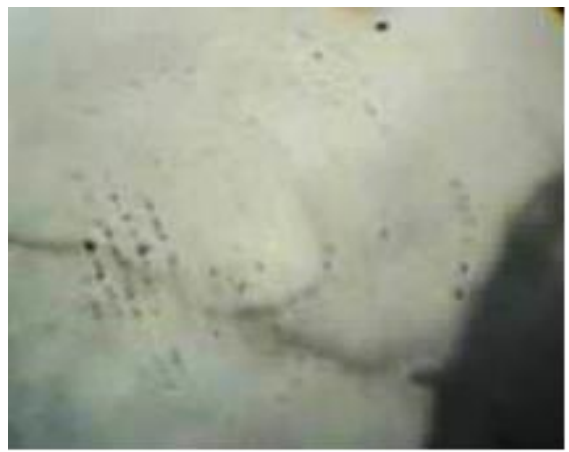

Fig. 8. The interface between the composite Restoration and the Variolik $\mathrm{N}$ resin after the immersion in artificial saliva

In case of ceramic inlays, after 70 hours in the artificial saliva at the level of the interface, imperfections and irregularities are observed, less obvious than in the case of the Meron Plus fixing material, but more obvious than in the previous situation, of the inlays from the light cured composite resin (Fig. 9).

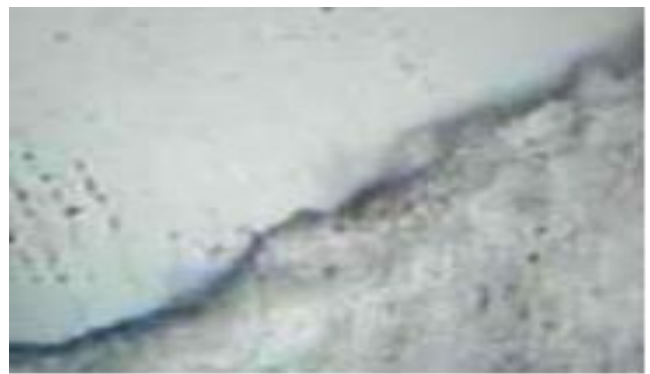

Fig. 9. The interface between the ceramic restoration and the Variolik $\mathrm{N}$ resin after the immersion in artificial saliva

In citric acid, the attack of the cement is more pronounced (Figs. 10 and 11), in some areas the loss of the substance is deep, probably caused by the contraction of the cement under the action of the strong acid environment. There are no significant differences between the two types of inlay-composite and ceramic.

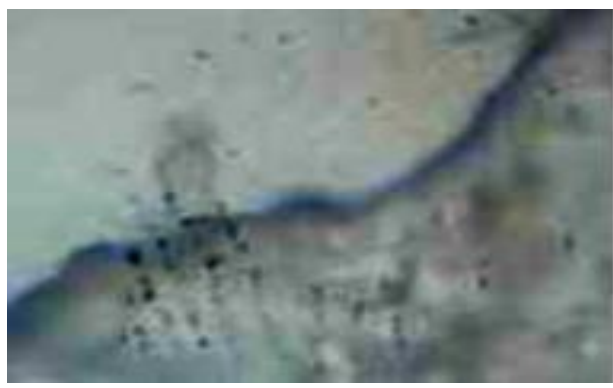

Fig. 10. The interface between composite restoration and Variolik $\mathrm{N}$ resin after the immersion in citric acid

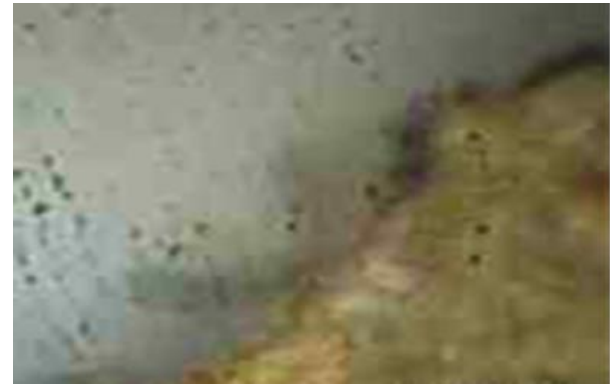

Fig. 11. The interface between ceramic restoration and Variolik $\mathrm{N}$ resin after the immersion in citric acid

The clinical success of any fixed dental restoration is strongly related, among numerous other factors, to the fixing procedure. The deficiencies occurred during the inlay cementation lead to defects, either of depth or on surface, which often lead to clinical failure. Each of these luting materials has specific physical and chemical properties, without any of them proving to be perfect for any clinical situation. [11-13] 
Although the shape of the preparations and the restoration material are the factors of great importance for the longevity of the inlays, the fixing material acts as a barrier against marginal microbial infiltration, sealing the dental-prosthetic interface [14].

In the case of aesthetic inlays, self- or light cured composite resins are preferred for fixation, but the polymerization contraction of these resins is higher than other fixing materials.

This volumetric change generates a load of almost $130 \mathrm{~kg} / \mathrm{cm}$ between the composite and the cavity walls. The tensions require the connection between the two contact surfaces, resulting in spaces that can allow the infiltration of the area. Also, the stress may exceed the tension strength of the enamel, resulting in cracks or fractures of the dental tissues at the level of the interface [15-17]. The lower the volume of the polymer in the composite resin, the greater the volume change during the polymerization reaction. Therefore, it is recommended to use composite resins with a large number of particles and a high module of elasticity for fixing intra-tissue inlays [18-21].

The self-cured cementing material undergoes more important changes, both in artificial saliva and in acid environment. The light cured cementation resin provides a smooth, continuous interface, without any irregularities, being more stable even after the immersion in the two studied environments.

\section{Conclusions}

The materials used for inlay restorations, the dimension of the dental-prosthetic space and the fixing material are factors of great importance, which influence the quality and the behavior of these devices on the long-term.

By analyzing the two cementing materials studied, we can conclude that the self-cured resin, even if it initially allows a good marginal adaptation, after the action of the artificial saliva and the citric acid, it presents important depreciation that will affect the longevity of the inlays. This behavior is explained by the fact that these materials undergo significant volumetric changes during the grip reaction.

The Variolink N light-cured resin ensures a better marginal closure, being even more stable in the acid environment; the connection proved to be stronger between the fixing material and the composite resin from which the restoration was performed.

This study shows that the restoration material does not influence the quality of the dental-prosthetic joint, only the fixing material contributing to the obtainment a good quality marginal closure.

\section{References}

1. BACIU, S., BERECE, C., FLOREA, A., BURDE, A., NEGRUTIU, ML., SZUHANEK, C., SINESCU, C., DUMA, V.F., MANOLE, M.A, Rev. Chim.(Bucharest), 68, no. 6, 2017, p. 1316.

2. DIACONU, D., TATARCIUC, M., VITALARIU, A., STAMATIN, O., FOIA, L., CHECHERITA, L., Mat. Plast. 51, no. 3, 2014 , p. 271.

3. LUCA, O., VITALARIU, A., HOLBAN-CIOLOCA, C., TATARCIUC, M., DIACONU-POPA, D., Mat. Plast. 56, no. 3, 2019, p. 625

4. ABDELFATTAH, A., ABDELAZIZ, K.M., J. Adv. Prosthodont., 7, no. 6, 2015, p. 446

5. HOPP, C.D., LAND, M.F., Clin. Cosmet. Investig. Dent., 5, 2013, p. 21

6. CRITCHLOW, S., Evid. Based Dent., 13, no. 2, 2012, p. 49.

7. ABDELAZIZ, K.M., AL-QAHTANI, N.M., AL-SHEHRI, A.S., ABDELMONEAM, A.M., J. Investig. Clin. Dent., 3, 2012 , p. 142.

8. ZORZIN, J., BELLI, R., WAGNER, A., PETSCHELT, A., LOHBAUER, U., J. Adhes. Dent., 16, no. 6, p. 541.

9. BRUNTON, P.A., RATNAYAKE, J., LOCH, C., VEERASAMY, A., CATHRO, P., LEE, R., Int. J. Dent., 2019.Article Number: Jan 10;2019:5210162. doi: 10.1155/2019/5210162.

10. FRON CHABOUIS, H., SMAIL FAUGERON, V., ATTAL, J.P., Dental Materials, 29, no. 12, 2013, p. 1209.

11. MORIMOTO, S., REBELLO, D.E., SAMPAIO, F.B., BRAGA, M.M., SESMA, N., OZCAN, M., J. Dent. Res., 95, no. 9, 2016 , p. 985.

12. SOARES, C.J., FARIA-E-SILVA, A.L., RODRIGUES, M.P., VILELA, A.B.F., PFEIFER C.S., TANTBIROJN, D.,VERSLUIS, A., Braz. Oral Res. , 31, no. supll.1: e62, 2017, p. 49.

13. ODIAN, G., Principles of polymerization. 3rd edition. Wiley-Interscience, New York, 1991.

14. KIM, R.J., KIM, Y.J., CHOI, N.S., LEE, I.B., J. Dent., 43, no. 4, 2015, p. 430.

15. VERSLUIS, A., TANTBIROJN, D., Relationship between shrinkage and stress. IGI Global; 2009.

16. PEREIRA, R.D., VALDÍVIA, A.D., BICALHO, A.A., FRANCO, S.D., TANTBIROJN, D., VERSLUIS, A., Oper Dent., 40, no 5, 2015 , p. 206.

17. PATRASCU, I., ILICI, R., GALBINASU, B.M., Rom. J. Oral Rehab., 10, no. 3, 2018, p. 6

18. TARABOAntA, I., StOleriU, S., IOVAN, G., MOLdOVANU, A., GEORGESCU, A., RUSU NEGRAIA, M., ANDRIAN, S., Mat. Plast. 55, no. 2, 2018, p.238.

19. TATARCIUC, M., VITALARIU, A., LUCA, O., AUNGURENCEI, A., AUNGURENCEI, O., FRATILA, D., DIACONU-POPA, D., Rev.Chim. (Bucharest), 69, no. 2, 2018, p. 407.

20. TANCUlESCU, O., DOLOCA, A., VIERIU, R.M., MOCANU, F., IFTENI, G., VITALARIU, A., SOLOMON, S., IOANID, N., IOVAN, G., Rev.Chim. (Bucharest), 68, no. 1, 2017, p. 94

21. BOLAT, M., BOSINCEANU, D.G., SANDU, I.G., BOSINCEANU, D., SURLARI, Z., BALCOS, C., SOLOMON, O., VITALARIU, A., Mat. Plast. 56, no. 1, 2019, p. 144.

$\overline{\text { Manuscript received: } 25.11 .2019}$ 